\title{
Melbourne Connect
}

Andrew Turpin, School of Computing and Information Systems, University of Melbourne

Paul Gruba, School of Languages and Linguistics, University of Melbourne

9 Dec 2021

\section{Motivation and Context}

Seeing the pandemic as an opportunity to reset the relationship between academics and the public, the ViceChancellor of the University of Melbourne Professor Duncan Maskell wrote "to keep Australia's businesses and organisations functioning competitively, we need a steady pipeline of highly educated people able to deal with uncertainty, solve complex and unforeseen problems, be adaptable, and keep a bigger picture in view" (Maskell, 01 Sept, 2021). We agree; universities have much to offer, and our work here seeks to inform ways to create that "steady pipeline" through a renewed vision of leadership across research-intensive institutions.

More than ever, a variety of forces demand that universities be more explicit in engaging with adoption and application of their research. Once deemed acceptable to publish in peer-reviewed journals, for example, academics are now asked to demonstrate the impact of their intellectual output. While a deceptively simple objective, the landscape in which impact must be demonstrated is very complex. For academics and their industry partners, success now relies on building and increasing the number of relationships between participants across three sectors with different working cultures: government, industry, and academia.

While straightforward directives and the imposition of metrics to incentivise behaviour are useful such approaches have often been imported from other contexts and lack firm foundation. For example, counting the number of startups linked to a university is a simple measure of the institutions' contribution to innovation, but does not speak to questions such as how many fail, are unethical, are comprised of one person, damage the environment, and so on. From institutional experience, we have seen colleagues establish a series of SMART goals for the purposes of stimulating engagement and framing leadership. To wit: if they achieve Specified, Measurable, Assessed, Realistic, and Timebound goals, colleagues deem their work successful. However, while these goal-oriented approaches may stimulate some desired behaviours, they also encourage gaming of the metrics, leading to emergent behaviours that are not desired (Goodhart/Strathern's Law). They also lead to an audit mentality of evaluation such that ticking the box of achieving a metric is enough for success without encouraging reflection, development and lessons that can be taken into other projects.

Further, given a focus on achieving goals, organisations lack flexibility to respond to new challenges. Goals cannot be constantly chopped and changed without severely lowering moral and increasing staff turnover, thus locking organisations into glacial and incremental change processes. Large Australian universities are particularly at fault here, with the enslavement of academic staff to targets and metrics, creativity and inspiration often have to work around institutional policies and processes to succeed. In this context, the creation of Melbourne Connect at The University of Melbourne is a chance to reimagine goals, evaluation methods and staff empowerment. Not only is this desirable from the point of view of the academic workforce, it is essential for Melbourne Connect to become an "innovation precinct". Getting research adopted usefully in society (the definition of innovation assumed here) requires agility that current university systems do not allow. To quote our Vice Chancellor and Provost: "we must take risks". Trying to achieve a metric that overly simplifies scholarship and innovation stifles chances to take risks.

Seeing the need to embrace complexity as a starting point for institutional leadership, Patton (2018) argues that effectiveness principles should be the foundation of choice. Demonstrated application and success in a principlefocused leadership can be found in work that includes, for example, Blue Marble Evaluation, the Global Alliance for the Future of Food, and the Paris Declaration (see suggested resources).

A set of principles, if well designed, can allow flexibility and risk-taking while being:

- a basis for decision making that is collegial, transparent, and defensible;

- a foundation to guide, inspire, and bring together a diverse workforce; and

- a framework to monitor, evaluate, and develop programs. 
In response to calls to embrace complexity and navigate uncertainty (Maskell, 2021), we worked collaboratively to set out seven principles that can be used to underpin effective leadership in Melbourne Connect: connection, mutual support, sharing, resourcefulness, advocacy, innovation, and future focused (see Figure 1 and Table 1). As researchers ourselves, we understand that our current work is preliminary and offer it here to incite further discussion and development. The present study arises out of the 'lived experience' of enacting our own attempts at leadership and focuses on a key innovation at our university.

To illustrate our work, we describe the development of the effectiveness principles up to the point of endorsement by the Melbourne Connect Steering Committee in 2021 in the next Section. Briefly, Melbourne Connect is a newly created 'hybrid' organisation designed to harness the discoveries of academic research with the experienced insights of industry in ways that foster impact, promote uptake, and position each partner to succeed in areas of data intensive and digital markets. As its name implies, Melbourne Connect is designed to stimulate mutually beneficial partnerships with the University and industry leaders. Ideally, it is an organisation that enacts Maskell's vision of embracing complexity and preparing a new generation of knowledge workers who can work through uncertainty.

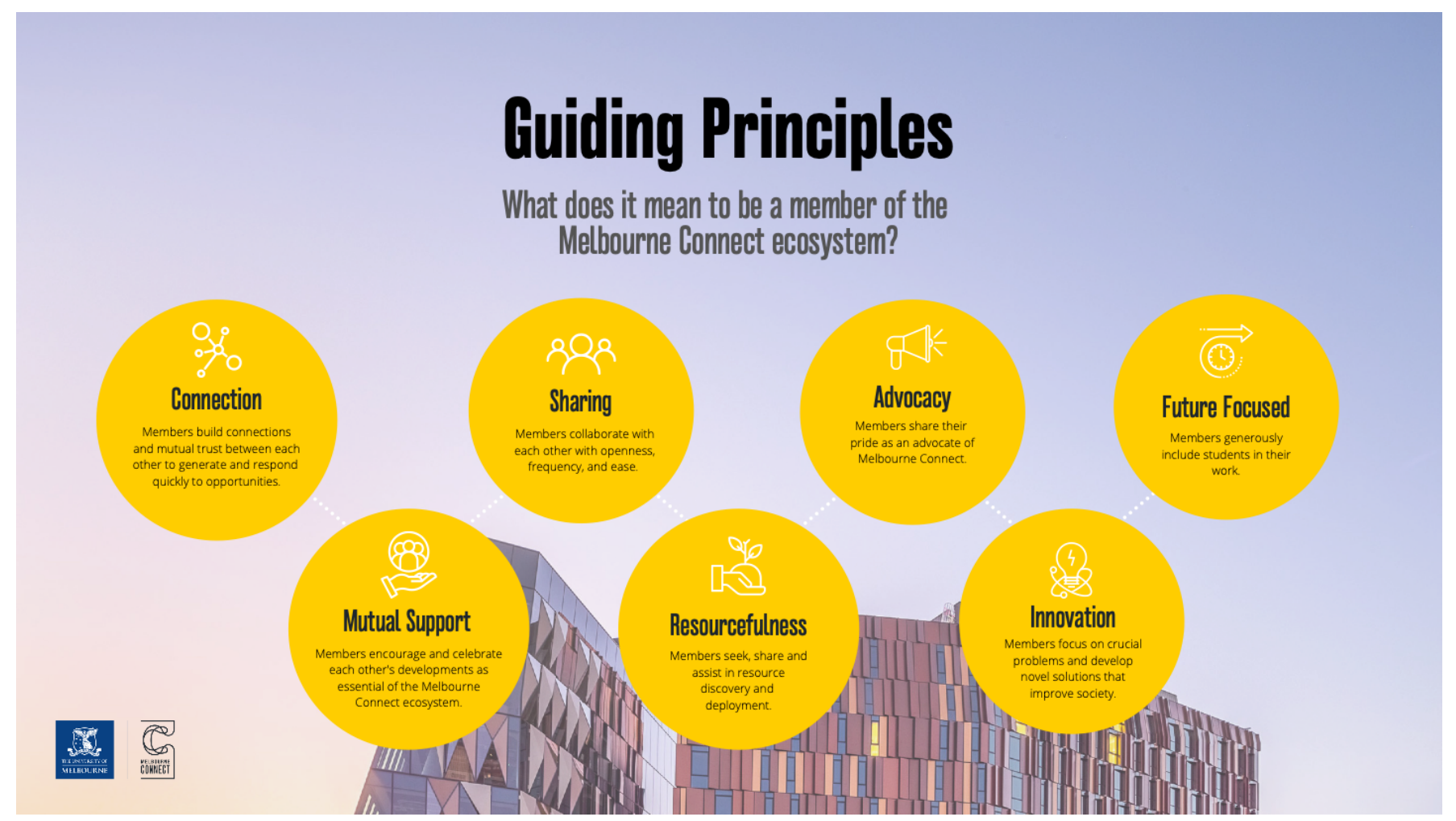

Figure 1 The seven guiding principles of Melbourne Connect (2021). 


\begin{tabular}{|c|c|c|}
\hline Principle & & What do we hope to result from the principle being followed? \\
\hline Connection. & $\begin{array}{l}\text { Members build connections } \\
\text { and mutual trust between } \\
\text { each other to generate and } \\
\text { respond quickly to } \\
\text { opportunities. }\end{array}$ & $\begin{array}{l}\text { Professional and social networks of members will be constructed in the ecosystem. } \\
\text { Through these networks: } \\
\text { - new challenges and opportunities will emerge; and } \\
\text { - opportunities that arise can be taken advantage of quickly by utilising the existing networks of trusted } \\
\text { members that are in place. } \\
\text { A network of trusted peers will drive change so that: } \\
\text { - academic members positively engage in innovation; and } \\
\text { - all members engage comfortably with a variety of academic pursuits. }\end{array}$ \\
\hline Mutual support. & $\begin{array}{l}\text { Members encourage and } \\
\text { celebrate each other's } \\
\text { development as essential } \\
\text { parts of the Melbourne } \\
\text { Connect ecosystem. }\end{array}$ & $\begin{array}{l}\text { By supporting and developing each other, members will increase capability for interaction, innovation, and } \\
\text { entrepreneurialism. Through this increased capability, society's problems can be more efficiently and effectively } \\
\text { addressed. } \\
\text { Support from peers will increase staff satisfaction and Melbourne Connect will be seen as a workplace of choice. } \\
\text { Celebrating success will build a shared culture that will encourage members to pursue shared values. }\end{array}$ \\
\hline Sharing. & $\begin{array}{l}\text { Members collaborate with } \\
\text { each other with openness, } \\
\text { frequency, and ease. }\end{array}$ & $\begin{array}{l}\text { Members in Melbourne Connect will share scientific knowledge, technical and practical know-how, information, and } \\
\text { business intelligence. Through sharing, members will feel more connected, and many problems will be exposed to } \\
\text { potential solutions. }\end{array}$ \\
\hline Resourcefulness. & $\begin{array}{l}\text { Members seek, share, and } \\
\text { assist in resource discovery } \\
\text { and deployment. }\end{array}$ & $\begin{array}{l}\text { Members will help each other find money, equipment and talent that can resource projects and programs of } \\
\text { innovation. This will lead to more staff and equipment across the whole ecosystem being employed to solve } \\
\text { important problems. }\end{array}$ \\
\hline Advocacy. & $\begin{array}{l}\text { Members share their pride as } \\
\text { an advocate for Melbourne } \\
\text { Connect. }\end{array}$ & $\begin{array}{l}\text { Melbourne Connect will be recognised locally, nationally, and internationally as a generator of innovative ideas. } \\
\text { Leaders from within Melbourne Connect will be visible within broader society. } \\
\text { Members of Melbourne Connect will be aware of what Melbourne Connect is and what it is achieving. } \\
\text { Governments will set favourable legal, regulatory, economic, and tax policies to allow innovation to occur. }\end{array}$ \\
\hline Innovation & $\begin{array}{l}\text { Members focus on crucial } \\
\text { problems and develop novel } \\
\text { solutions that improve } \\
\text { society. }\end{array}$ & $\begin{array}{l}\text { Melbourne Connect will generate many projects and programs that are socially responsible, practical, and } \\
\text { sustainable. The projects and programs will find unique solutions to challenge the status quo that will be developed } \\
\text { and adopted by industry, professions, or governments. } \\
\text { A pathway from inspiration to adoption will be available through Melbourne Connect. }\end{array}$ \\
\hline Future Focused. & $\begin{array}{l}\text { Members generously include } \\
\text { students in their work. }\end{array}$ & $\begin{array}{l}\text { By including students in all facets of Melbourne Connect: new perspectives will be brought to bear on problems; } \\
\text { talent will be developed for sustaining Melbourne Connect; and Melbourne Connect will differentiate itself from } \\
\text { other innovation precincts. }\end{array}$ \\
\hline
\end{tabular}


Frustrated by our earlier attempts to incorporate "evaluative thinking" (Patton, 2018b) into an earlier initiative, we started thinking of adopting a principles-focused basis for leadership decisions in 2019. Our first drafts were dismal and clumsy. What exactly were effectiveness principles, and how could we write them such that they aligned with concepts set out by Patton (2018a) and be acceptable to colleagues? We continued to revise initial drafts in the following years and, at crucial times, applied them as a basis for decisions that required particular attention. Eventually, our own leadership decisions came to be informed by principles.

It turns out, however, that principles were not sufficient for our purposes. In an environment that now often publishes "roadmaps", we needed a way to convey to colleagues that we had a structured plan in mind. And, indeed, that the structure illustrated a way to resolve a key challenge that we collectively facing. Reading through evaluation reports and guidelines (see suggested resources), we came to understand the importance of crafting a Theory of Change in our work. Proponents of Theory of Change argue that planners set out a sufficient level detail of how and why an effort will be adopted ahead of enacting the changes. We took a cue from such reports, and found that "backward mapping" to be a useful illustration of our intentions.

The value of that experience was put to the test when Turpin was offered the opportunity to serve in a leadership position in the newly formed Melbourne Connect. Again, we began to draft: Would a principles-focused approach help to underpin the ways the start-up organisation saw itself and sought to inspire innovation? From drafting through to critiques from new colleagues, the principles are becoming a basis for decision making. As agreed, the principles will be used to evaluate current progress of Melbourne Connect; in the coming years, we will continue revisions, adjustments, and insights as to provide a firm foundation for the Melbourne Connect innovation ecosystem.

The methodology used to derive the principles was based primarily on the work of Patton and the Theory of Change as sketched on the website of the Center for Theory of Change (CTC). The framework for assisting decision making was based on the Global Alliance for the Future of Food.

\section{Step 1 - Backwards Mapping as a Theory of Change}

Firstly, using the Backwards Mapping approach of the CTC, we attempted to capture the major activities that would be required to achieve Melbourne Connect's vision. This is shown in Figure 2. This is the result of several iterations with key leaders of Melbourne Connect.

\section{Step 2 - Identify Principles}

We began by grouping the lettered boxes from Figure 2 into themes and then attempted to write a draft principle to cover each theme. This is shown in Table 2. The next stage was to evaluate and refine the text using Patton's GUIDE method. In particular, we attempted to write the thesis of the principle: why would people adhere to the principle; what behaviours and benefits should arise? Almost as importantly, we also wrote the antithesis, a process by which we removed ambiguity and imprecision in previous drafts. As an exercise, we also included rules and goals that projects or units might adopt to implement the principle at a smaller scale that the entire ecosystem. We also scored each principle against Patton's 4 categories in each of the 5 GUIDE mantra's, refining text accordingly.

\section{Step 3 - Develop Framework}

Finally, to encourage adoption and use of the principles, we used Table 1 of the Global Alliance for Future Food as a framework that people could use to assess their decisions and programs for adherence to the principles. 


\begin{tabular}{|c|c|c|}
\hline Principle & Text & Desired behaviours \\
\hline Connection. & $\begin{array}{l}\text { Members build connections and mutual } \\
\text { trust between each other to generate and } \\
\text { respond quickly to opportunities. }\end{array}$ & C: Connections across domains are facilitated \\
\hline Mutual support. & $\begin{array}{l}\text { Members encourage and celebrate each } \\
\text { other's development as essential parts of } \\
\text { the Melbourne Connect ecosystem. }\end{array}$ & $\begin{array}{l}\text { L: Training is available to build capability } \\
\text { M: Success is celebrated }\end{array}$ \\
\hline Sharing. & $\begin{array}{l}\text { Members collaborate with each other with } \\
\text { openness, frequency, and ease. }\end{array}$ & D: There are forums for sharing problems \\
\hline Resourcefulness. & $\begin{array}{l}\text { Members seek, share, and assist in } \\
\text { resource discovery and deployment. }\end{array}$ & $\begin{array}{l}\mathrm{N} \text { : External funding sources are identifiable and } \\
\text { utilised } \\
\mathrm{K} \text { : Talent from outside the ecosystem is } \\
\text { recruited if necessary }\end{array}$ \\
\hline Advocacy. & $\begin{array}{l}\text { Members share their pride as an advocate } \\
\text { for Melbourne Connect. }\end{array}$ & $\begin{array}{l}\text { F: Leaders from within Melbourne Connect will } \\
\text { be visible within broader society. } \\
\text { I: Leaders within the ecosystem are visible in } \\
\text { society } \\
\text { G: MC members identify as part of the } \\
\text { ecosystem }\end{array}$ \\
\hline Innovation & $\begin{array}{l}\text { Members focus on crucial problems and } \\
\text { develop novel solutions that improve } \\
\text { society. }\end{array}$ & $\begin{array}{l}\text { E: Problems and pain points are identified } \\
\text { B: Unique solutions that challenge the status } \\
\text { quo are developed and adopted } \\
\mathrm{J}: \text { There is a path to adoption for solutions }\end{array}$ \\
\hline Future Focused. & $\begin{array}{l}\text { Members generously include students in } \\
\text { their work. }\end{array}$ & $\begin{array}{l}\text { H: Students are included to expand their } \\
\text { experiences } \\
\text { H: Students are included as contributors }\end{array}$ \\
\hline
\end{tabular}




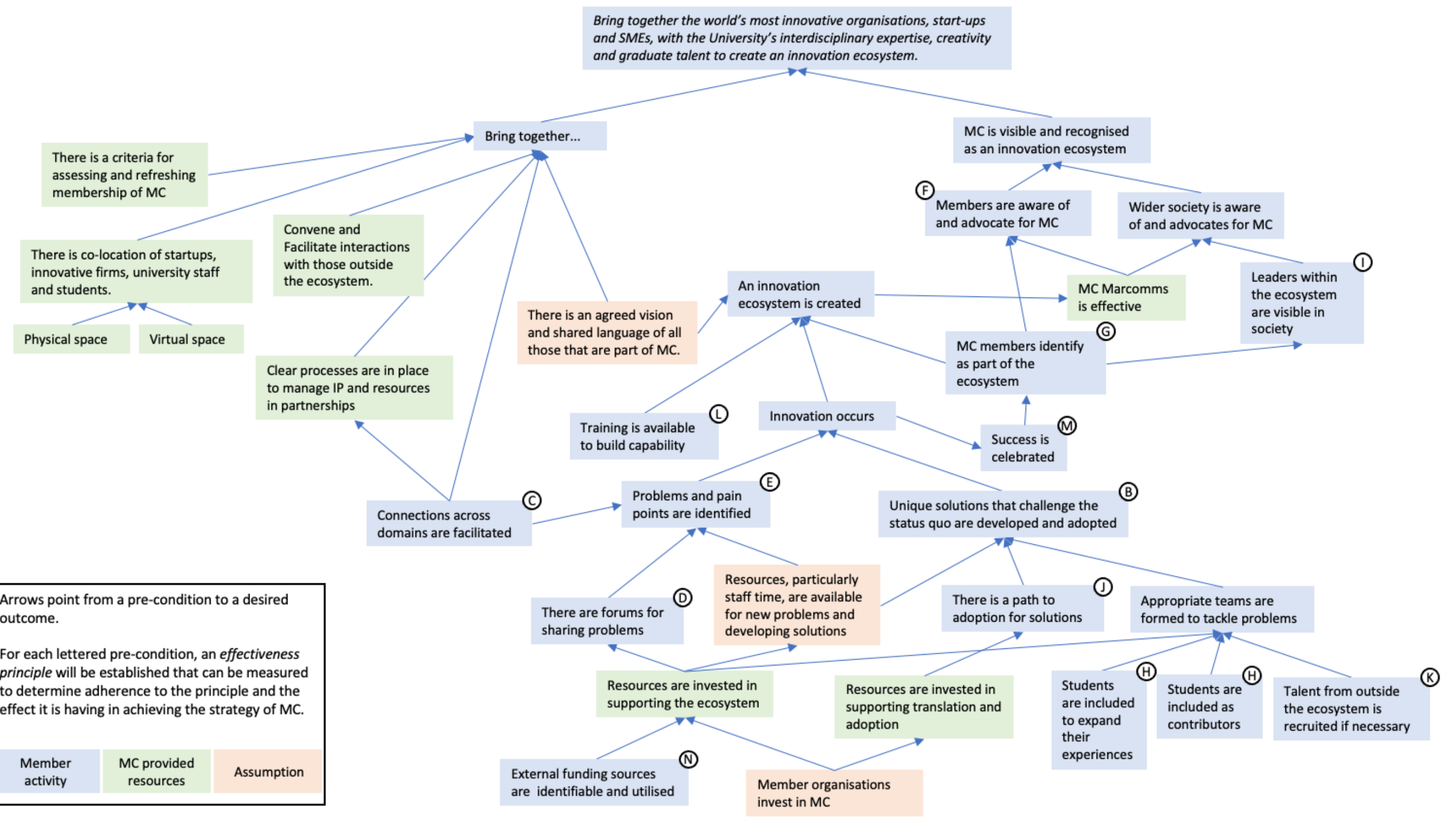

Figure 2: Backwards mapping of activities required to achieve Melbourne Connect's vision 


\begin{tabular}{|c|c|c|c|c|}
\hline Principle & Thesis & Antithesis & As a rule & Example Goals \\
\hline $\begin{array}{l}\text { Connection. } \\
\text { Members build } \\
\text { connections and } \\
\text { mutual trust between } \\
\text { each other to } \\
\text { generate and respond } \\
\text { quickly to } \\
\text { opportunities. }\end{array}$ & $\begin{array}{l}\text { Connecting members, through } \\
\text { network-building, relationship } \\
\text { brokering, and trust-building between } \\
\text { members who might not previously } \\
\text { have worked together lays important } \\
\text { groundwork for agility and innovation. }\end{array}$ & $\begin{array}{l}\text { Active networking is not required. } \\
\text { Members will find each other and } \\
\text { build relationships when there is } \\
\text { a need. This is a net saving in } \\
\text { time. }\end{array}$ & $\begin{array}{l}\text { All members must devote a } \\
\text { fraction of their time to } \\
\text { interacting within the } \\
\text { Melbourne Connect } \\
\text { ecosystem. } \\
\text { Organisations must have a } \\
\text { line item in their budget to } \\
\text { support networking in the } \\
\text { ecosystem. }\end{array}$ & $\begin{array}{l}\text { Spend one hour a week talking } \\
\text { to others in Melbourne } \\
\text { connect. } \\
\text { Reward staff for new } \\
\text { partnerships. }\end{array}$ \\
\hline $\begin{array}{l}\text { Mutual support. } \\
\text { Members encourage } \\
\text { and celebrate each } \\
\text { other's development } \\
\text { as essential parts of } \\
\text { the Melbourne } \\
\text { Connect ecosystem. }\end{array}$ & $\begin{array}{l}\text { Recognising others in the ecosystem } \\
\text { increases the attractiveness of the } \\
\text { ecosystem to top talent and increases } \\
\text { advocacy. Some members will need } \\
\text { training in areas of innovation. }\end{array}$ & $\begin{array}{l}\text { Problem solving and impact is its } \\
\text { own reward, there is no need to } \\
\text { celebrate successes. We can } \\
\text { easily pick up the skills we need } \\
\text { without mutual support. }\end{array}$ & $\begin{array}{l}\text { All successful projects must } \\
\text { be reported for an annual } \\
\text { reward scheme. } \\
\text { Everyone must attend } \\
\text { training. }\end{array}$ & $\begin{array}{l}\text { I will attend all award } \\
\text { ceremonies run for the } \\
\text { ecosystem. } \\
\text { I will help others find the } \\
\text { training they need. }\end{array}$ \\
\hline $\begin{array}{l}\text { Resourcefulness. } \\
\text { Members seek, share, } \\
\text { and assist in resource } \\
\text { discovery and } \\
\text { deployment. }\end{array}$ & $\begin{array}{l}\text { Resources for research and translation } \\
\text { are necessary to sustain the } \\
\text { ecosystem. Members should seek to } \\
\text { gain from grant opportunities that } \\
\text { support staff, students, and solution } \\
\text { building and translation. }\end{array}$ & $\begin{array}{l}\text { Members are already paid to do } \\
\text { digital research and its translation } \\
\text { which is cheap. We should not } \\
\text { waste time on writing grant } \\
\text { applications. } \\
\text { Grants are competitive, I do not } \\
\text { want to increase competition by } \\
\text { sharing. }\end{array}$ & $\begin{array}{l}\text { All members should get one } \\
\text { external grant every } 3 \text { years. }\end{array}$ & $\begin{array}{l}\text { I will apply for at least one } \\
\text { grant every two years. }\end{array}$ \\
\hline $\begin{array}{l}\text { Advocacy. } \\
\text { Members share their } \\
\text { pride as an advocate } \\
\text { for Melbourne } \\
\text { Connect. }\end{array}$ & $\begin{array}{l}\text { Having Melbourne Connect as a } \\
\text { recognised brand for innovation in all } \\
\text { things digital and data will increase } \\
\text { the opportunities for all ecosystem } \\
\text { members. Visibility of leaders will } \\
\text { improve government and industry } \\
\text { support. }\end{array}$ & $\begin{array}{l}\text { Individual firms and researchers } \\
\text { must build their own personal } \\
\text { brand in order to attract funding } \\
\text { and customers. } \\
\text { Leaders should focus on their } \\
\text { teams. }\end{array}$ & $\begin{array}{l}\text { All publications talks and } \\
\text { public appearances must } \\
\text { acknowledge Melbourne } \\
\text { Connect. }\end{array}$ & $\begin{array}{l}\text { I will include a slide on } \\
\text { Melbourne Connect in all } \\
\text { public talks I deliver, or } \\
\text { documents I produce. } \\
\text { I will increase my media } \\
\text { engagements. }\end{array}$ \\
\hline $\begin{array}{l}\text { Innovation. } \\
\text { Members focus on } \\
\text { crucial problems and }\end{array}$ & $\begin{array}{l}\text { The main motivation for Melbourne } \\
\text { Connect as an innovation precinct is to }\end{array}$ & $\begin{array}{l}\text { Innovation must be preceded by } \\
\text { basic research and deep } \\
\text { knowledge. Communicating this }\end{array}$ & $\begin{array}{l}\text { All members should solve at } \\
\text { least two problems a year }\end{array}$ & $\begin{array}{l}\text { Get at least one solution } \\
\text { adopted in practice every two } \\
\text { years. }\end{array}$ \\
\hline
\end{tabular}




\begin{tabular}{|c|c|c|c|c|}
\hline $\begin{array}{l}\text { develop novel } \\
\text { solutions that improve } \\
\text { society. }\end{array}$ & $\begin{array}{l}\text { solve problems and have that solution } \\
\text { adopted in society. }\end{array}$ & $\begin{array}{l}\text { knowledge to other researchers } \\
\text { should be the focus of MC. }\end{array}$ & $\begin{array}{l}\text { and have that solution } \\
\text { adopted. }\end{array}$ & \\
\hline $\begin{array}{l}\text { Sharing. } \\
\text { Members collaborate } \\
\text { with each other with } \\
\text { openness, frequency, } \\
\text { and ease. }\end{array}$ & $\begin{array}{l}\text { Sharing opportunities and knowledge } \\
\text { will lead to new ideas and } \\
\text { opportunities for all members of the } \\
\text { ecosystem. }\end{array}$ & $\begin{array}{l}\text { To be the most productive one } \\
\text { must focus and specialise, letting } \\
\text { irrelevant opportunities fall to } \\
\text { others. Teaching should be } \\
\text { reserved for students only. }\end{array}$ & $\begin{array}{l}\text { Make every effort to find } \\
\text { someone who can take on a } \\
\text { problem. } \\
\text { Participate in seminars and } \\
\text { workshops in the ecosystem. }\end{array}$ & $\begin{array}{l}\text { Pass on the three } \\
\text { opportunities each year to } \\
\text { other staff. }\end{array}$ \\
\hline $\begin{array}{l}\text { Future Focused. } \\
\text { Members generously } \\
\text { include students in } \\
\text { their work. }\end{array}$ & $\begin{array}{l}\text { Innovation requires diverse skills. } \\
\text { Further, students will benefit from the } \\
\text { experience of being involved, and } \\
\text { talent development is essential for } \\
\text { long term sustainability of innovation. }\end{array}$ & $\begin{array}{l}\text { It is more efficient if I solve } \\
\text { problems by myself, or with } \\
\text { existing partners. Including } \\
\text { students slows me down. }\end{array}$ & $\begin{array}{l}\text { All teams should include at } \\
\text { least one student. }\end{array}$ & $\begin{array}{l}\text { All of my GRs are involved in } \\
\text { an MC problem. } \\
\text { Get } 3 \text { interns. }\end{array}$ \\
\hline
\end{tabular}


Acknowledgements

Thanks to Stephanie Kwok for the graphic design of Figure 1, and Melissa Verdino, Georgia von Guttner and Phil Callahagn for helpful discussions on early drafts of the principles and framework.

\section{References and suggested resources}

Maskell, D. “Time to reset the relationship between universities and the public'. The Australian, 01 Sept 2021

Patton, M. Q. (2018a). Principles-focused evaluation: The GUIDE. Sage.

Patton, M. Q. (2018b). A historical perspective on the evolution of evaluative thinking. In A. T. Vo \& T. Archibald (Eds.), Evaluative thinking. New directions for evaluation, 158, 11-28. https://doi.org/10.1002/ev.20325

Blue Marble Evaluation

https://bluemarbleeval.org/

Consolidated Framework for Implementation Research (CFIR)

https://cfirguide.org/

Evaluation Strategy: Office of the Chief Economist

Evaluation Strategy 2017-2021 (industry.gov.au)

Global Alliance for the Future of Food

https://futureoffood.org/

Paris Declaration and Accra Agenda for Action

https://www.oecd.org/dac/effectiveness/parisdeclarationandaccraagendaforaction.htm

Statement of Principles for Australian Innovation Precincts

$\underline{\text { Statement of Principles for Australian Innovation Precincts }}$ Department of Industry, Science, Energy and Resources

Theory of Change: Backward mapping and connecting outcomes

https://www.theoryofchange.org/what-is-theory-of-change/how-does-theory-of-change-work/example/backwards-mapping/ 